\title{
Budidaya Sayur Secara Hidroponik dan Ikan Lele dengan Teknologi BioMaxi untuk Memupuk Jiwa Enterpreneurship
}

\author{
Rosmaiyadi $^{1}$, Slamat Fitriyadi², Susan Neni Triani ${ }^{3}$ \\ STKIP Singkawang ${ }^{1,2,3}$. \\ rosmaiyadialong@gmail.com ${ }^{1}$, ahmadfitriyadi521@gmail.com ${ }^{2}$, susannenitriani@gmail.com ${ }^{3}$
}

\begin{abstract}
Developing entrepreneurship for the students should be done starting from of primary and secondary education. The major obstacles experienced by the school in general are not the inclusion of entrepreneurial material in the curriculum contained in the school subjects. Similarly, the partner in this case MTs Al Fatah Singkawang. The constraints that the partners of the community service Program are the limitation of capital (cost), human resources, technology and also the location of land that is narrow enough to implement activities for students. Program activities are conducted with hydroponic vegetable cultivation and catfish cultivation with Bioflok technology which is carried out by 30 students MTs Al Fatah and also involve the practitioners of hydroponic vegetable cultivation and also fish farming practitioners Catfish with Bioflok system. This activity was held from May 2019 until December 2019. Hydroponic vegetable farming and catfish cultivation activities with Bioflok technology started with the preparation of cultivation media until the process of cultivation. Results show that students can already practice vegetable cultivation in hydroponics and fish farming with BIOMAXI technology and this activity plays a major role in cultivating the entrepreneurship of students.
\end{abstract}

Keywords: School; Entrepreneurship; Hydroponic; Vegetable; BioMaxi; Enterpreneurship

\begin{abstract}
Abstrak
Menumbuhkembangkan jiwa kewirausahaan bagi siswa-siswi sebaiknya dilakukan mulai dari pendidikan dasar dan menengah. Hambatan besar yang dialami sekolah pada umumnya adalah belum tersisipkannya materi kewirausahaan di dalam kurikulum yang tertuang dalam mata pelajaran di sekolah. Begitu pula halnya dengan Mitra dalam hal ini MTs Al Fatah Singkawang. Kendala yang Mitra Program Pengabdian Masyarakat ini adalah keterbatasan modal (biaya), sumberdaya manusia, teknologi dan juga lokasi lahan yang cukup sempit untuk menerapkan kegiatan berwirausahan bagi siswa-siswi. Program kegiatan yang dilaksanakan adalah dengan Budidaya Sayur Secara Hidroponik dan Budidaya Ikan Lele Dengan Teknologi Bioflok yang dikuti oleh 30 orang santri MTs Al Fatah dan juga melibatkan praktisi budidaya sayur hidroponik dan juga praktisi budidaya ikan lele dengan sistem bioflok. Kegiatan ini dilaksanakan dari bulan Mei 2019 sampai dengan Desember 2019. Kegiatan Budidaya Sayur Secara Hidroponik dan Budidaya Ikan Lele Dengan Teknologi Bioflok ini dimulai dengan persiapan media budidaya sampai dengan proses penen hasil budidaya. Hasil kegiatan menunjukkan bahwa siswa-siswi sudah dapat mempraktekan budidaya sayur secara hidroponik dan budidaya ikan lele dengan teknologi biomaxi dan kegiatan ini berperan besar menumbuhkan jiwa kewirausahaan siswa-siswi.
\end{abstract}

Kata Kunci: Sekolah; Kewirausahaan; Hidroponik; Sayur; BioMaxi, Enterpreneurship 


\section{A. Pendahuluan}

Sekolah adalah sebuah lembaga yang dirancang untuk pengajaran siswa atau murid di bawah pengawasan pendidik atau guru (Idi, 2011). Sebagian besar Negara memiliki sistem pendidikan formal yang umumnya wajib dalam upaya menciptakan peserta didik yang mengalami kemajuan setelah melalui proses pembelajaran. Menurut negara namanama untuk sekolah itu bervariasi, akan tetapi umumnya termasuk sekolah dasar dan sekolah menengah. Sekolah menyelenggarakan aktivitas belajar dan mengajar dengan menerima murid dan memberikan pelajaran kepada murid-murid sesuai dengan tingkat, jurusan dan lainnya. Menilik dan mengacu pada Undang-Undang Nomor 20 Tahun 2003 tentang Sistem Pendidikan Nasional Nasional Bab I Ketentuan Umum Pasal 1 ayat 8 menyatakan bahwa jenjang pendidikan adalah tahapan pendidikan yang ditetapkan berdasarkan tingkat perkembangan peserta didik, tujuan yang akan dicapai, dan kemampuan yang dikembangkan (Depdiknas, 2003). Dalam Undang-Undang tersebut disebutkan bahwa jenjang pendidikan formal di Indonesia terdiri atas pendidikan dasar, pendidikan menengah, dan pendidikan tinggi.

Pendidikan Dasar adalah pendidikan umum yang lamanya sembilan tahun, diselenggarakan selama enam tahun di Sekolah Dasar atau sederajat dan tiga tahun di Sekolah Menegah Pertama atau sederajat. Pendidikan Menengah adalah pendidikan yang diselenggarakan bagi lulusan pendidikan dasar serta menyiapkan peserta didik menjadi anggota masyarakat yang memiliki kemampuan mengadakan hubungan timbal balik dengan lingkungan sosial budaya dan alam sekitar serta dapat mengembangkan kemampuan lebih lanjut dalam dunia kerja atau pendidikan tinggi. Lama pendidikan yaitu tiga tahun, bentuk satuan pendidikan menengah terdiri atas Sekolah Menengah Umum, Sekolah Menengah Kejuruan, Sekolah Menengah Keagamaan, Sekolah Menengah Kedinasan, dan Sekolah Menengah Luar Biasa. Pendidikan Tinggi merupakan kelanjutan pendidikan menengah yang diselenggarakan untuk menyiapkan peserta didik menjadi anggota masyarakat yang memiliki kemampuan akademik dan profesional yang dapat menerapkan, mengembangkan dan menciptakan ilmu pengetahuan, teknologi dan atau kesenian. Begitu pula halnya tatanan sekolah di bawah Kemenag Republik Indonesia, jenjang sekolah menurut Kementrian Agama Republik Indonesia adalah Madrasah Ibtidaiyah (MI) adalah jenjang paling dasar pada pendidikan formal di Indonesia, setara dengan Sekolah Dasar, yang pengelolaannya dilakukan oleh Kementerian Agama.

Pendidikan Madrasah Ibtidaiyah ditempuh dalam waktu 6 tahun, mulai dari kelas 1 sampai kelas 6. Lulusan Madrasah Ibtidaiyah dapat melanjutkan pendidikan ke Madrasah Tsanawiyah (MTs) atau sekolah menengah pertama. Sementara itu Madrasah Aliyah (MA) adalah jenjang pendidikan menengah pada pendidikan formal di Indonesia, setara dengan sekolah menengah atas, yang pengelolaannya dilakukan oleh Kementerian Agama. Pendidikan Madrasah Aliyah ditempuh dalam waktu 3 tahun, mulai dari kelas 10 sampai kelas 12. MTs Al Fatah adalah salah satu sekolah atau madrasah yang berada di Kota Singkawang yang bernaung di bawah Kementrian Agama Kota Singkawang. MTs Alfatah, merupakan sekolah yang dikelola oleh Yayasan Shuffah Hizbullah Al Fatah, selain MTs Al Fatah, Yayasan ini juga menanungi MA Al Fatah dan juga MI Al Fatah. Dan kesemua Madrasah ini menyatu dalam Pondok Pesantren Al Fatah. Visi MTs Al Fatah adalah mewujudkan generasi yang berakhlak 
al-Karimah dengan pola Tarbiyah Shuffah Rasulullah Shallallahu 'Alaihi Wasallam sehingg adapat menjadi Ulul Albab yang mampu menegakkan syari'at Islam yang rahmat bagi seluruh alam. Sekolah agama ini menerapkan dua jenis kelas, yaitu kelas regular dan juga kelas Tahfidz (penghafal Qur'an).

Salah satu tujuan dari MTs Al Fatah adalah mempersiapkan generasi terbaik agar dapat memanfaatkan ilmu pengetahuan dan teknologi bagi kemaslahatan umat manusia. Pemanfaatan ilmu pengetahuan dan teknologi dapat diaplikasikan dengan berbagai cara. Salah satunya adalah dengan memanfaatkan pengetahuan dan teknologi untuk dapat memiliki jiwa kewirausahaan. Jiwa kewirausahaan sedapat mungkin dapat ditumbuhkembangkan sejak di Pendidikan Dasar dan Menegah (Mulyani, 2011). Pelaksanaan kewirausahaan di sekolah merupakan suatu hal yang tidak bertentangan dengan butir-butir kebijakan nasional dalam bidang pendidikan yang terdapat dalam dokumen RPJMN 2010-2014. Salah satu dari 6 substansi inti program aksi bidang pendidikan diarahkan demi tercapainya pertumbuhan ekonomi adalah menciptakan lapangan kerja atau kewirausahaan. Hal ini belum pernah dilaksanakan di lokasi mitra MTs Al Fatah.

Menumbuhkembangkan jiwa kewirausahaan bagi siswa-siswi di sekolah dasar dan menengah dilakukan dengan menyisipkan kewirausahaan dalam Kurikulum ataupun dengan langsung mempraktekkan kegiatan wirausaha itu sendiri. Di MTs Al Fatah, kurikulum yang digunakan belum menyisipkan materi kewirausahaan di dalamya. Untuk melakukan hal terebut akan memerlukan waktu dan tenaga yang cukup banyak. Oleh karena itu pengusul program ingin mengembangkan jiwa kewriausahaan siswa-siswi yang ada di MTs Al Fatah dengan mempraktekkan langsung kegiatan berwirausaha dengan melalui usaha budidaya sayur dan juga budidaya ikan lele. MTs Al Fatah dibangun di atas tanah yang tidak luas, dan lokasinya juga menyatu dengan MA Al Fatah dan MI Al Fatah, oleh karena itu tidak memungkinkan untuk diterapkannya melakukan usaha budidaya sayur dan budidaya ikan lele dengan menggunakan cara yang konvensional. Oleh karena itu diperlukan teknik budidaya sayur dan ikan lele yang hanya memerlukan lahan dan biaya yang ringan, sehingga lebih efisien. Salah satu teknik budidaya sayur yang dapat diterapkan dengan kondisi mitra adalah dengan teknik hidroponik.

Teknik hidroponik adalah cara produksi tanaman dalam air yang mengandung unsur hara. System hidroponik juga merupakan cara produksi yang sangat efektif (Raffra, 1993). Selain dengan melakukan kegiatan wirausaha dengan bercocok tanam sayur melalui taknik hidroponik, dapat juga dilakukan dengan budidaya ikan lele. Salah satu teknik budidaya ikan lele yang efesien adalah dengan menggunakan kolam terpal (Sumarna, 2018). Dengan menggunakan kolam terpal sebagai media budidaya ikan lele akan mengefesiensi anggaran dan juga lahan dalam proses produksinya (Gunawan, 2017). Selain itu teknik ini sangat ramah lingkungan, sehingga sangat cocok untuk digunakan (Hudaidah, 2017).

\section{B. PELAKSAAAN DAN METODE}

Metode yang digunakan untuk merealisasikan program PKM budidaya sayur secara hidroponik dan budidaya lele di MTs Al Fatah adalah SKPP (sosialisasi, pembentukan kelompok, dan pelatihan, dan pendampingan). Tahap awal yang dilakukan adalah dengan melakukan sosialisasi pada masyarakat sasaran. Program selanjutnya adalah langsung dibentuk kelompok- 
kelompok kecil untuk memudahkan proses pelatihan. Pelatihan nantinya dilakukan dengan melibatkan mahasiswa serta tim Penyuluh. Program inipun akan diberi pendampingan agar dapat berjalan secara optimal bagi masyarakat sasaran.

Untuk dapat mengoptimalkan cara bercocok tanam secara hidroponik dan juga budi daya ikan lele pada kolam terpal perlu juga dilakukan pelatihan. Tujuan dari pelatihan ini agar para siswa terlibat langsung dalam proses penanaman hingga pemanenan sayur dengan teknik hidroponik dan juga budidaya ikan lele pada kolam terpal. Proses kegiatan dilaksanakan pada sisa lahan MTs Al Fatah yang tersisa untuk diajsikan lahan hidroponik dan juga budidaya ikan lele yaitu berada di belakang Asrama Putra.

Untuk mengoptimalisasikan proses bercocok tanam secara hidroponik dan budidaya lele dapat dilakukan melalui beberapa tahapan, yaitu rekrutmen Mahasiswa. Mahasiswa yang akan dilibatkan dalam program ini adalah dia yang ingin belajar dan mau terlibat aktif dalam rangkaian program. Oleh sebab itu, mahasiswa yang terlibat dapat berasal dari berbagai angkatan dan program studi.

Pembekalan mahasiswa, mahasiswa yang sudah terjaring melalui proses rekrutmen selanjutnya diberikan pembekalan. Pembekalan ini diberikan langsung oleh pengusul dan penyuluh dari Dinas Pertanian dan Kehutanan Kota Singkawang. Tujuan pembekalan adalah agar pendamping program ini mengetahui hal-hal teknis yang diperlukan sebelum maupun saat program dilaksanakan.

Sosialisasi program, hal awal yang perlu dipersiapkan untuk mendukung kelancaran program adalah melakukan proses perijinan. Perijinan tersebut di lakukan di MTs Al Fatah Singkawang, kemudian Ketua Yayasan Pondok Pesantren Al Fatah dan Juga Kepala Kementrian Agama Kota Singkawang yang menjadi sasaran program. Izin yang diberikan dari masing-masing tingkatan tersebut diharapkan akan memperlanjar proses sosialisasi program pada mitra sasaran.

Persiapan perlengkapan, pada tahap ini mitra sasaran (Siswa siswi MTs Al Fatah) diberi arahan untuk mempersiapkan hal-hal teknis untuk mendukung program. Persiapan tersebut misalnya dengan menyiapkan alat dan bahan yang telah disediakan oleh pengusul untuk melaksanakan program.

Pembentukan kelompok, siswa siswi yang menjadi sasaran program akan dibagi menjadi beberapa kelompok. Setiap kelompok nantinya akan diberi tentor atau pendamping yaitu mahasiswa dan juga guru MTs Al Fatah yang telah mendapatkan program pembekalan. Kelompokkelompok kecil ini juga akan didampingi penyuluh dari Dinas Pertanian dan Kehutanan Kota Singkawang.

Pengenalan kegiatan, setiap kelompok belajar diberi pengenalan segala macam pelalatan serta bahan yang digunakan untuk bercocok tanam secara hidroponik dan juga budi daya ikan lele pada kolam terpal. Pengenalan ini dilakukan dengan menampilkan video maupun gambar relevan terkait.

Pembuatan media tanam hidroponik dan kolam terpal. Para siswa bersama-sama mahasiswa membuat media tanam hidroponik dan juga kolam terpal untuk budidaya lele di lokasi yang sudah ditentukan.

Praktik Cocok Tanam dan budi daya lele. Para siswa wajib mempersiapkan alat dan bahan untuk praktek hidroponik dan budi daya ikan lele pada kolam terpal. Mahasiswa, dosen pengusul mencontohkan cara bercocok tanam dengan teknik hidroponik dan juga budidaya lele sedangkan para siswa siswi mengikuti instruksi tersebut. Praktik ini pun 
dipandu juga oleh penyuluh dari Dinas Pertanian dan Kehutanan Kota Singkawang.

Monitoring, tim pengusul, mahasiswa, maupun penyuluh melakukan monitoring secara bertahap. Tujuan monitoring adalah untuk mengetahui masalah yang ada di lokasi program. Evaluasi, evaluasi dilakukan untuk memastikan bahwa program PKM yang diterapkan berjalan dengan baik.

\section{C.HASIL DAN PEMBAHASAN}

\section{a. Tahap Persiapan}

Tahapan persiapan dalam pelaksanaan PKM ini meliputi perizinan kepada Mitra, rekrutmen mahasiswa yang ikut dalam kegiatan PKM, rekrutmen nara sumber/penyuluh kegiatan, pembekalan kepada mahasiswa yang nantinya bertugas dalam pelaksanaak kegiatan PKM sampai dengan selesai dan sosialisasi kegiatan PKM yang dilaksanakan kepada seluruh unsur di dalam Pondok Pesantren Al Fatah Singkawang.

\section{b. Tahap Pelaksanaan Budidaya \\ 1. Budidaya Sayur Dengan Teknik \\ Hidroponik}

Budidaya sayur dengan teknik Hidroponik yang menjadi program yang pertama dalam kegiatan PKM ini dilakukan dengan beberapa tahap, diantaranya adalah pembentukan kelompok kecil budidaya sayur, tahap persiapan peralatan dan perlengkapan dari media tanam hidroponik, tahap pembuatan media tanam hidroponik serta praktik bercocok tanam dengan teknik hidroponik.

\section{a) Tahap Pembentukan Kelompok Kecil \\ Tahapan Budidaya Sayur Dengan} Teknik Hidroponik diawali dengan pembentukan kelompok-kelompok kecil budidaya sayur. Pada kegiatan ini dibentuk 2 kelompok yang memiliki tugas untuk melaksanakan budidaya sayur dengan teknik hidroponik. Masing-masing kelompok terdiri dari 1 orang guru di MTs Alfatah, 1 Orang mahasiswa dan 10 orang siswa/santri MTs Al Fatah Singkawang. Masing-masing kelompok ini mendapatkan paket hidroponik yang dirawatnya selama kegiatan PKM berjalan. Tiap-tiap kelompok bertanggung jawab atas sayur yang dibudidyakannya tersebut, mulai dari tahapan pembuatan media sampai dengan tahapan panen dan pemasaran hasil panen sayur.

b) Perakitan/Instalasi Media Tanam

Hidroponik

Pembuatan media tanam hidroponik dilakukan oleh dosen pelaksana pengabdian beserta dua kelompok kecil dalam budidaya sayur hidroponik dan didampingi oleh seorang penyuluh yang sudah berpengalaman dalam bercocok tanam hidroponik. Seluruh anggota kelompok mengambil perannya masing-masing dalam proses perakitan/instalasi dari media tanam ini dengan arahan dan bimbingan dari dosen pelaksana pengabdian dan juga penyuluh. Selain itu pekerjaan kelompok-kelompok ini dibantu juga oleh tukang las, yang mengerjakan penopang atau pondasi dari media tanam hidroponik ini.

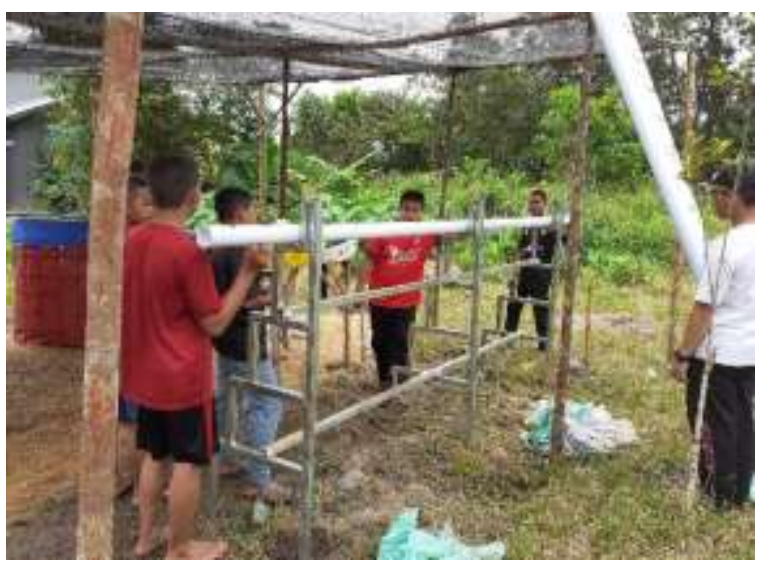

Gambar 1. Proses Instalasi Media Hidroponik 
c) Praktik Budidaya Sayur Dengan Teknik

Hidroponik

Praktik budidaya sayur hidroponik ini diawali dengan persiapan air nutrisi pada hidroponik. Air nutrisi yang digunakan umumnya digunakan adalah Nutrisi $A B$ Mix (Nugraha dan Susila, 2015) Khusus untuk sayuran daun. Hal ini sejalan dengan pendapat Nugraha dan Susila Pembuatan nutsisi AB Mix ini dengan mencampurkan Nutrisi A dengan 5 liter air bersih pada wadah, mencampurkan nutrisi $\mathrm{B}$ dengan 5 liter Air Bersih dan disimpan pada wadah yang terpisah. Untuk pencampuran nutrisi AB Mix ini adalah dengan komposisi $5 \mathrm{ml}$ Larutan A dan $5 \mathrm{ml}$ Larutan B untuk perliter Air Nutrisi Siap Pakai.

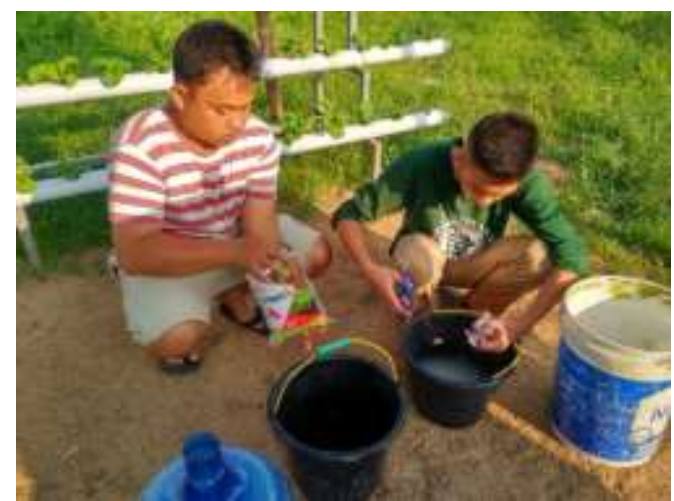

Gambar 2. Pembuatan Larutan Nutrisi

Tahapan selanjutnya adalah menyemai benih sayuran pada media hidroponik yaitu Rockwool. Sebelumnya rockwool dibasahkan pada wadah sebelum ditanam benih yang akan disemai. Waktu penyemaian adalah sekitar 7 sampai dengan 10 hari, dengan menempatkannya pada tempat yang terkena matahari dan memastikan bahwa rockwool tidak kering agar hasil semaian dapat tumbuh dengan baik dan normal.

Setelah proses penyemaian dilaksanakan, berikutnya adalah memindahkan bibit semai tersebut ke Netpot hidroponik. Waktu pembesaran sayur pada netpot adalah sekitar 20 sd 25 hari. Sehingga sayur tanaman hidroponik dapat dipanen. Namun dalam praktikna tidak semudah seperti teori yang ada. Karena ada beberapa kendala dan permasalahan yang dihadapai pada tahapan pembesaran sayur. Pada praktik pertama ini sayur yang dihasilkan masih kurang cukup besar, padahal sudah memasuki umur siap panen secara teori. Ada beberapa hal yang menjadi faktor penyebabnya, diantaranya dalah kontrol Air nutrisi yang masih belum baik, sehingga dimungkinkan sayuran mengalami kekurangan nutrisi. Yang kedua faktor penyebabnya adalah PH air nutrisi yang susah untuk dikondisikan, karena ketika menambahkan Air nutrisi, kelompok yang bertugas ini kurang memperhatikan $\mathrm{PH}$ air dari Nutrisi ini, $\mathrm{PH}$ air nutrisi yang baik bagi tanaman sayur adalah berkisar 5,5 sd 6,5 (Kustanti, 2014). Untuk mengatasi hal ini maka akan dilakukan pengecekan $\mathrm{PH}$ secara rutin pada air nutrisi, jika $\mathrm{PH}$ air rendah maka ditambahkan larutan PH Up untuk menaikan $\mathrm{PH}$ air agar sesuai dengan kriteria. Sementara jika PH air nutrisi tinggi, maka ditambahkan PH Down untuk menurunkan PH air agar sesuai dengan kriteria sayuran tersebut.

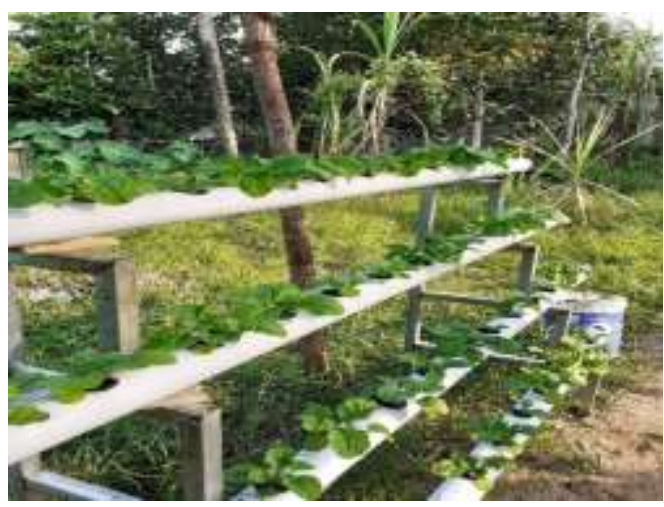

Gambar 3. Hasil Panen Hidroponik

2. Budidaya Ikan Lele Dengan Teknologi BioMaxi

Budidaya Ikan Lele Dengan Teknologi BioMaxi yang menjadi program yang kedua dalam kegiatan PKM ini dilakukan dengan beberapa tahap, diantaranya adalah 
pembentukanbkelompok kecil ternak lele, tahap persiapan peralatan dan perlengkapan dari media kolam terpal, tahap pembuatan media ternak lele dengan kolam terpal serta praktik memilihara ikan lele dengan teknik BioMaxi.

a) Tahap Pembentukan Kelompok Kecil

Tahapan Budidaya Ikan Lele Dengan

Teknologi BioMaxi diawali dengan pembentukankelompok-kelompok kecil budidaya lele. Pada kegiatan ini dibentuk 3 kelompok yang memiliki tugas untuk melaksanakan budidaya Ikan Lele Dengan Teknologi BioMaxi. Masing-masing kelompok terdiri dari 1 orang guru di MTs Alfatah, 1 Orang mahasiswa dan 10 orang siswa/santri MTs Al Fatah Singkawang. Masing-masing kelompok ini mendapatkan paket kolam lele yang dirawatnya selama kegiatan PKM berjalan. Tiap-tiap kelompok bertanggung jawab atas ikan lele yang dibudidyakannya tersebut, mulai dari tahapan pembuatan media sampai dengan tahapan panen dan pemasaran hasil budidaya ikan lele.

b) Perakitan/Instalasi Media Budidaya Lele

Pembuatan media tanam hidroponik dilakukan oleh dosen pelaksana pengabdian beserta dua kelompok kecil dalam budidaya sayur hidroponik dan didampingi oleh seorang penyuluh yang sudah berpengalaman dalam bercocok tanam hidroponik. Seluruh anggota kelompok mengambil perannya masing-masing dalam proses perakitan/instalasi dari media kolam terpal ini dengan arahan dan bimbingan dari dosen pelaksana pengabdian dan juga penyuluh.

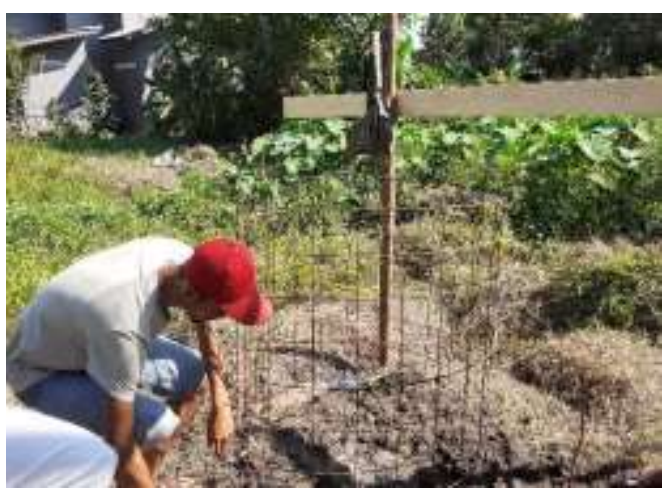

Gambar 4. Pemasangan Wiremes Untuk Penopang Kolam Terpal

c) Praktik Budidaya Ikan Lele Dengan Teknologi BioMaxi

Praktik budidaya Ikan Lele Dengan Teknologi BioMaxi dalam PKM ini menggunakan Probiotik Bioflokulan, karena probitoik ini lebih mudah dalam penggunaannya. Probitoik biflokulan adalah probitoik yang digunakan untuk menumbuhkan bioflok didalam kolam terpal sebagai makanan tambahan bagi ikan lele selama proses budidayanya mulai dari penaburan benih sampai dengan masa panen. Tahapan pertama dalam budidaya ikan lele dengan teknik biomaxi ini adalah dengan persiapan air. Tujuan persiapan air ini adalah untuk memastikan air yang digunakan untuk budidaya ikan lele ini baik dan siap untuk ditaburi bibit ikan lele. Langkah yang harus dilakukan dalam mempersiapkan air adalah dengan memasukkan air pada kolam terpal setinggi $70-90 \mathrm{~cm}$ diamkan selama satu hari dengan meberikan aerator. Pada hari kedua memasukkan probiotik bioflokulan $5 \mathrm{ml} / \mathrm{m}_{3}$ pada kolam terpal degan terlebih dahulu mencamuprkannya dengan air hingga terasa lebih cair. Dan diamkan air pada kolam ini selama 7 sd 10 hari agar bioflok agar benarbenar telah jadi pada air ini. 


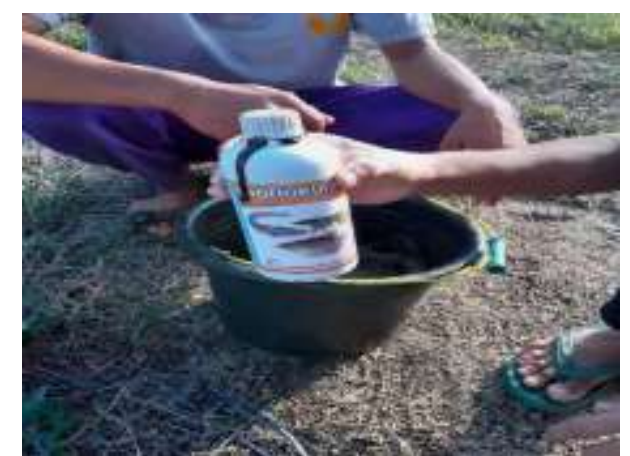

Gambar 5. Pengenceran Probiotik Bioflokulan

Tahapan selanjutnya adalah memastikan dengan benar bahwa biflok didalam kolam terpal ini sudah hidup dengan baik, sehingga bibit ikan lele dapat ditabar pada kolam terpal untuk pembesaran. Sebelum membeli bibit ikan lele, pastikan ikan lele tersebut adalah bibit yang sehat dan baik. Hal ini dapat dilihat dengan kekatifan bibit ikan ketika di air. Jika ikan aktif bergerak maka baiklah bibit ikan tersebut, jika senaliknya maka bibit ikan tidak baik. Dalam menebar bibit ikan pada kolam juga memiliki teknik tersendiri, agar ikan tidak mengalamai stres ketika masuk ke dalam kolam. Teknik yang digunakan adalah dengan membiarkan bibit ikan lele yang ada pada bungkus bibit mengapung dahulu dipermukaan air kolam, diamkan hingga suhu air dalam bungkus/kantong bibit ikan hampir sama dengan suhu air kolam. Setelah itu barulah bungkusan bibit ikan tersebut dapat dibuka. Setelah bibit ikan masuk ke dalam kolam, maka perlu dipastikan ikan tidak ada yang mengambang.

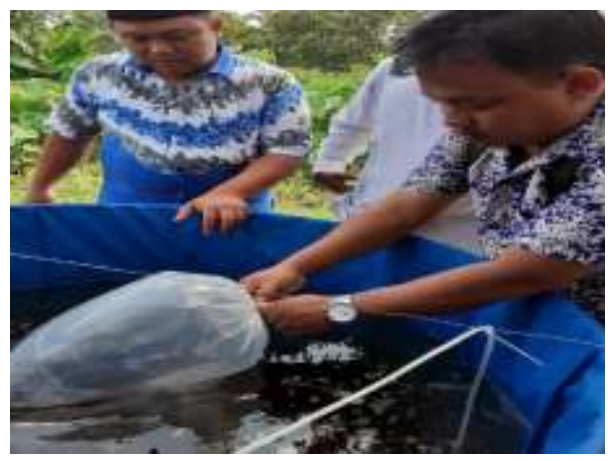

Gambar 6. Proses Penebaran Bibit Ikan Pada Kolam Terpal

Langkah selanjutnya adalah proses pembesaran ikan. Ada beberapa hal yang harus dilakukan dalam proses pembesaran ikan lele pada media kolam terpal bioflok ini. Yang pertama adalah pakan ikan harus dibibis terlebih dahulu, tujuan pembibisan pakan adalah agar pakan ikan lembut dan dengan mudah untuk dimakan oleh ikan, karena pada tahapan awal pembesaran ikan ini bibit ikan lele cukup susah dalam pemberian pakannya. Pakan diberikan 3 kali dalam satu hari, yaitu pagi siang dan malam. Porsi pekan pada ikan tergantung FCR ikan lele yang ada pada masing-masing kolam terpal. Yang kedua adalah pembuangan air ditiap harinya melalui kran pembuangan air, hal ini dilakukan agar kotoran ikan yang mengandung amoniak dapat terbuang. Setelah air dikurangi melalui kran pembuangan, maka air kemudian ditambah sesuai dengan air yang telah dikelaurkan tadi.

Dalam proses pembesaran yang telah dilakukan dalam kegiatan PKM ini ternyata kami dan masing-masing kelompok mengalami masalah. Masalah pertama yang dihadapi adalah matinya ikan lele pada masa pembesaran yaitu pada umur 14 sampai dengan 15 hari. Hal ini terjadi karena $\mathrm{PH}$ air yang tidak terkontrol pada saat penambahan air ditiap harinya. Sebaiknya $\mathrm{PH}$ air harus dikontrol untuk memasatikan ikan dapat tumbuh dan berkembang dengan baik (Monalisa, 2010) Untuk mengatasinya 
dengan menguras air kolam dan memberika treatmen air melalui penaburan garam dan kapur dolomit pada air kolam tersebut. Dan hasilnya ikan lele pada kolam tidak ada yang mati lagi.

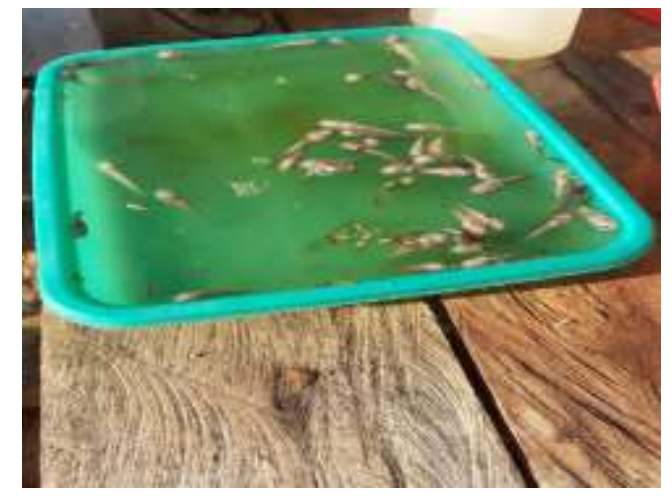

Gambar 7. Ikan Lele Yang Mati Akibat PH Air

Setalah mengalami kematian ikan pada masalah yang pertama, kemudian ikan kembali lagi ada beberapa yang mati karena terserang virus herpes. Ikan lele mangapung dipermukaan kolam, jika tidak segera diatasi makan akan banyak ikan yang mati nantinya. Langkah yang harus dilakukan selanjutnya adalah dengan memberika jus daun pepaya kepada ikan lele tersebut. Tujuannya adalah agar virus herpes pada ikan lele dapat teratasi dan ikan lele kembali sehat. Setelah diberikan jus daun pepaya tersebut, sampai dengan umur ikan 30 hari, ikan lele sehat semua. Dan ditaksirkan ikan dapat dipanen pada umur sekitar 2,5 bulan.

\section{PENUTUP}

\section{Simpulan}

Kesimpulan dari pelaksanaan kegiatan PKM ini adalah kegiatan berwirausaha Melalui Budidaya Sayur Secara Hidroponik dan Budidaya IkanLele Dengan Teknologi BioMaxi di MTs Al Fatah Singkawang dapat memancing siswauntuk memiliki jiwa kewirausahaan

Kegiatan berwirausaha Melalui Budidaya Sayur Secara Hidroponik dan
Budidaya IkanLele Dengan Teknologi BioMaxi di MTs Al Fatah Singkawang masih belum mencapaitarget panen yang dihasilkan, sehingga diperlukan usaha yang keras untuk memperolehhasil yang baik

\section{Saran}

Kegiatan PKM - Menuju Sekolah Berwawasan Kewirausahaan Melalui Budidaya SayurSecara Hidroponik dan Budidaya Ikan Lele Dengan Teknologi BioMaxi di MTs Al FatahSingkawang memerlukan keseriusan dan ketekunan dalam pelaksanaannya.

\section{E. DAFTAR PUSTAKA}

Depdiknas. 2003. Undang-Undang RI No.20 tahun 2003 Tentang Sistem Pendidikan Nasional. Jakarta : Depdikbud.

Gunawan, S. 2017. Kupas Tuntas Budidaya Bisnis Lele. Jakarta : Swadaya

Hudaidah, S., \& Yusup, M. W. 2017. Pemberdayaan Masyarakat Melalui Pengembangan Budidaya Ikan Lele Teknologi Bioflok di Kelurahan Pinang Jaya, Bandar Lampung, Lampung. Jurnal Sakai Sambayan, 1(1), 17-22.

Idi, A. 2011. Sosiologi Pendidikan (Individu, Masyarakat dan Pendidikan). Penerbit PT Raja Grafindo Persada : Jakarta.

Kustanti, I., Muslim, M. A., \& Yudaningtyas, E. 2014. Pengendalian Kadar Keasaman (pH) Pada Sistem Hidroponik Stroberi Menggunakan Kontroler PID Berbasis Arduino Uno. Jurnal Mahasiswa TEUB, 2(1).

Monalisa, S. S., \& Minggawati, I. 2010. Kualitas air yang mempengaruhi pertumbuhan ikan nila (Oreochromis sp.) di kolam beton dan terpal. Journal of Tropical Fisheries, 5(2), 526-530. 
Mulyani, E. 2011. Model Pendidikan Kewirausahaan di Pendidikan Dasar dan Menegah. Jurnal Ekonomi \& Pendidikan, volume 8 No 1

Nugraha, R. U., \& Susila, A. D. 2015. Sumber Sebagai Hara Pengganti AB mix pada Budidaya Sayuran Daun Secara Hidroponik. Jurnal Hortikultura Indonesia, 6(1), 11-19.

Raffar, K.A. 1993. Hydroponics in Tropica. International Seminar on Hydroponic Culture of High Value Crops in The Tropic in Malaysia, November 25-27, 1993

Sumarna, C. 2018. Budidaya Lele: Sistem Kolam Terpal Bundar dengn Teknoligi BioMacxi. Jakarta: PT Agro Media Pustaka. 